\title{
EDUARD BULWER UND SEINE WERKE.
}

Es war auffällig, dass wir von einem literarisch so beruhmten manne wie Bulwer bis vor kurzen gar keine eingehende lebensbeschreibung besassen, deren verfasser mit hilfe der verwanten des dichturs bisher unbenutztes material vor sich gehabt hätte. Denn wird auch jetzt niemand mehr Bulwer die bedeutung zuteilen, welche man ihm in den vierziger jahren, besonders in Deutschland, beigelegt hat, so lässt sich seine wichtigkeit für die entwicklung des romans während fast funfzig jahren durchaus nicht unterschätzen. Bulwer begann seine laufbahn als romanschriftsteller mit einem gemisch aus erinnerungen an Werther's leiden und an Byronsche gedichte im Falkland, es folgte dann der moderne gesellschaftliche roman, der kriminalroman; mit Devereux betrat er schon das gebiet des geschichtlichen romans im sinne Walter Scott's, in Zicei und Zanoni das der phantastischen erzählungen, es folgte dann der strengere geschichtliche roman wie ihn der Last of the Barons, Rienzi, Harold u. a. darstellen, endlich versuchte sich Bulwer mit grossem glttcke im humoristischen romane. Nimmt man dazu, dass derselbe verfasser es auch unternahm im Ernst Maltravers romane nach Deutschem muster, in den Pilgrims of the Rhine mährchenhafte stoffe zu bringen, so ist es wol nicht zuviel gesagt, wenn man behauptet, dass sich in B.'s romanen alle richtungen, welche diese dichtungsart in England während beinahe 50 jahren nahm, abspiegeln. Eine bedeutende stellung hat sich also Bulwer auf alle fälle in der englischen literatur errungen und schon deshalb hätte man erwarten sollen, dass bald nach seinem tode 1873 ein ausführliches leben Bulwer's erschienen wäre. Diese erwartung aber war um so gerechtfertigter als kaum ein anderer englischer schriftsteller soviel persönliches, sein eignes denken treu wider- 
spiegelndes in seine erzählungen getragen hat als gerade unser verfasser. Mit ansnahme desjenigen romanes, der, ohne verdienst, jetzt vielleicht der gelesenste geworden ist, von 'Night and Morning', finden wir uberall die reichste fulle von lebenserfahrung und tiefem studium in die erzählungen eingestreut. Bulwer's werke lassen sich daher ohne eine eingehende lebensbeschreibung nur mangelhaft verstehen, umgekehrt kann sein leben nur in verbindung mit seinen werken betrachtet werden!

Endlich erschien 1883 die lang erwartete beschreibung unter dem titel: 'The Life, Letters, and Literary Remains of Edward Bulwer, Lord Lytton, by his Son'. London, Kegan Paul, Trench \& Co. 1883. Vol. I. II.

Wenn je das alte sprichwort 'Was lange währt, das gut wird' seine berechtigung hatte, so ist es hier! Wir haben jetzt eine so ausführliche lebensbeschreibung Bulwer's zugleich mit einem abdrucke aller einigermassen wichtigern hinterlassenen werke als wir uns nur wünschen können. Hier erfahren wir denn auch durch das vorwort, warum bis 1883 niemand der etwa an eine eingehende lebensbeschreibung unseres verfassers gehen wollte von den verwanten literarisch unterstutzt worden war. In einem briefe an seinen sohn, der sich nach seinem tode vorfand, sprach Bulwer die hoffnung aus, dass sein sohn die von ihm selbst begonnene lebensbeschreibung vollende. Nur in diesem falle solle die autobiographie auch veröffentlicht werden. In diese schrift sollte der sohn auch von hinterlassenen werken und entwtirfen aufnehmen, was ihm gut scheine, alles andere aber solle vernichtet werden.

Nach solchen bestimmungen konnte also kein fremder zu diesen wichtigen papieren gelangen: dem sohne aber war es zur ehrenpflicht gegentiber dem andenken seines vaters gemacht, die lebensbeschreibung abzufassen.

Und man muss gestehen, soweit das werk vorliegt, hat sich der sohn in trefflichster weise seiner aufgabe erledigt. Eine ganz ungeahnte menge von aufklärung gewährt diese lebensbeschreibung. Wir merken bald, dass nicht nur die bisherigen nachrichten uber des dichters leben ganz unzuverlässig waren, sondern dass der sohn selbst in der autobiographie des vaters wichtige angaben $\mathrm{zu}$ berichtigen fand. 
Gleich über das geburtsjahr und den geburtsort Bulwer's waren bisher falsche angaben verbreitet. Ausserdem berichtigte der sohn noch einen merkwtirdigen fehler seines vaters. Bulwer selbst gab wol den 25. mai als tag seiner geburt an, doch das jahr verschwieg er oder erklärte dasselbe als 'a Cretan mystery'.1 Doch muss man aus manchen äusserungen annehmen, dass er glaubte, er sei 1805 geboren, während jetzt festgestellt ist, dass er am 25. mai 1803 das licht der welt erblickte. Dies ergibt sich aus dem kirchenbuch von St. Mary-le-bone, Middlesex. Merkwürdig bleibt ja allerdings, dass der dichter laut eintrag im selben kirchenbuche erst am 15. märz 1810 getauft wurde, doch dies bliebe nicht weniger merkwürdig, wenn man 1805 als geburtsjahr annehmen musste. Auch als 1854 ein astrolog Bulwer das horoskop stellte, wurde (mittwoch) der 25. mai 1803 als geburtstag B.'s angenommen. 1803 steht nun also als geburtsjahr fest. Aber auch uber den ort der geburt war man bisher im irrtum: man gab immer Heydon Hall in Norfolk an ${ }^{2}$, doch macht Bulwer (s. 74 unseres werkes), so bestimmt die angabe, er sei zu London, Baker Street 31 geboren, dass daran nicht zu zweifeln ist. ${ }^{3}$ Noch eine sonderbare annahme Bulwer's scheint sich, nach seines sohnes angabe, als unbegründet herauszustellen: nämlich dass Eduard Bulwer drei brtdder gehabt habe. Wilhelm, der älteste bruder, war 1799 geboren und starb 1877; Heinrich, geboren 1801, starb 1872, dann erwähnt B. noch eines andern bruders, der allerdings gleich nach seiner geburt gestorben sei ${ }^{4}$, doch dem vorhandengewesensein eines solchen bruders widerspricht der sohn aufs entschiedenste.

Die Autobiographie, die in das werk aufgenommen ist, bildet den inhalt des ersten bandes und erstreckt sich bis zum jahre 1825 einschl., dem 22. lebensjahre Bulwer's.

Die ersten sieben kapitel des buches sind den vorfahren Bulwer's gewidmet, im achten geht der verf. dann auf seine

1 In der Autobiography wird nur angeben ' $I$ was born on a certain twenty-fifth of May, about eight 0 ' clock in the morning, and in Baker Street, Portman Square, no. 31'.

2 So steht neuerdings z. b. wider in der 13. aufl. des Conversationslexicon von Brockhaus, während sich der verfasser dieses artikels doch gerade auf unsere biographie beruft!!

3 Vgl. anm. 1 und das Life s. 4.

- Vgl. s. 74 und s. 3. 
eltern tuber. Unter den Lytton's ist die interessanteste gestalt die des grossvaters, des gelehrten Richard Warburton Lytton, zugleich zeigt aber anch gerade seine geschichte und die von Elisabeth Joddrell, seiner frau, dass des dichters ehe nicht die erste unglickliche in der familie war. Aus der Bulwerschen geschichte sei erwähnt, dass Bulwer's grossvater väterlicherseits in Heydon Hall viel mit Eugen Aram, der damals lehrer in der nähe war, umgang gehabt haben soll, auch zwei tanten unseres schriftsteller von demselben in neuern sprachen unterrichtet worden sein sollen. Im 8. kapitel bis 13 . einschl. wird die vermählung und das familienleben der ältern bis zum tode des vaters, Juli 1807 , berichtet. Wir sehen daraus, dass die ehegatten nicht ungltcklich miteinander lebten, dass aber General Bulwer ein zu soldatischer charakter war um ein sehr zartfuhlender gatte zu sein, obgleich er seine frau gewiss liebte. Nach des mannes tod ging Elisabeth Bulwer nach London, wo ihre mutter, getrennt von ihrem gatten, lebte. Der zweite sohn zog ganz in das haus der grossmutter. Der älteste, Wilhelm, der Heydon Hall dereinst besitzen sollte, war in einer schulanstalt. So blieb Eduard allein bei der mutter. Die nächsten abschnitte behandeln die frthesten eindrttcke and erinnerungen des dichters. Auch erfahren wir, dass Bulwer schon im 7. jahre dichtete und dass sein erstes gedicht Heinrich V. und Agincourt besang (wol nur eine umdichtung einer gehörten ballade), sein zweites, aus demselben jahre, eine spielgefährtin verherrlichte. Von grossem einflusse auf das ganze leben Bulwer's war dann der Dez. 1810 erfolgte tod seines grossvaters Lytton, durch den nun seine mutter in den besitz von Knebworth kam. Dieselbe entschloss sich auf den stammsitz zu ziehen und so verliess Bulwer London. Auch in andrer hinsicht wurde der tod des grossvaters bedeutsam fur den dichter, indem auf eine zeit die bedeutende btichersammlung desselben in das haus der tochter kam und B. gelegenheit hatte die bucher zu durchstöbern. Am meisten zogen ihn Southey's tubersetzung des Amadis und Spencer's Faery Queen an.

Das zweite buch der Autobiographie umfasst Bulwer's schulzeit. In der ersten pension fuhlte er sich so unglticklich, dass seine mutter schon nach vierzehn tagen ihn wider herausnahm, in der zweiten dagegen blieb er etwa zwei jahre, ohne 
aber nutzen davon zu haben. Dann kam er, seiner gesundheit wegen, in eine schule von Dempster zu Brighton, darauf in die des Dr. Hooker zu Rottendean. Dies war eine schule, welche wirklich von einfluss auf des dichters entwicklung war. Nicht nur erwachte hier seine liebe zur Englischen literatur, er fand anch gelegenheit in einer schulerzeitung eigne gedichte zu veröffentlichen. Allein da er hier als dichter bekannt wurde, warf später Dr. Hooker den verdacht auf ihn, er habe ein spottgedicht auf seine frau gemacht und der direktor, der vorher Bulwer sehr geneigt war, bestand nun darauf, dass er die schule verlasse. Gegen ende des jahres 1818 verliess der dichter Rottendean. Wie er als schulknabe in dieser zeit war, schildert er uns in seinem bruchstucke 'Lionel Hastings', Vol. I cap. 1.' Von gedichten erwähnt er (aus dieser zeit) in einem briefe eine 'small Ode in imitation of Milton's Allegro upon a Poker'. Dieser brief ist vom 2. Nov. 1818 und ans 1819 haben wir ein gedicht auf den tod des mädchens, welchem eine seiner allerersten dichtungen gegolten hatte. Bulwer sollte nun nach Eton oder durch einen hauslehrer unterrichtet werden. Ein besuch an ersterem orte führte zu keiner entscheidung, ebensowenig aber konnte man sich fur einen der vielen hauslehrer, welche sich meldeten, entscheiden. Bis sich ein passender mann fände, sollte Bulwer wider in eine schule kommen, doch bald verliess er, in folge eines streites mit dem direktor, dieselbe wider.

Damit endete Bulwer's schulzeit. Da der dichter aber noch nicht gleich zur universität sollte, so wurde er in Ealing von Rev. Charles Wallington mit einigen andern jungen männern noch unterrichtet und auf die universität vorbereitet. Diese zeit wurde sehr wichtig fur ihn aus zwei grunden. Erstlich veranlasste Wallington B.'s mutter, dass sie ein bändehen gedichte ihres sohnes drucken liess. 1820 erschien: 'Ismael, an Oriental Tale with other Poems by Edward George Lytton Bulwer. Written between the Age of Thirteen and Fifteen'. Ferner aber verliebte er zur damaligen zeit sich zum erstenmale und diese ungltuckliche liebe tubte einfluss auf seine dichtung.

Zur zeit, als B. seine eigne geschichte aufzeichnete, es

${ }^{2}$ Vgl. s. 176 ff. 
war dies wol zwischen 1852-1855', beurteilt er diese erzeugnisse seines geistes ganz vorurteilsfrei ${ }^{2}$; anders war dies naturlich zur zeit, als dieselben erschienen. In einem gleichzeitigen briefe an seine mutter meint B., dass es sich sehr empfähle, die gedichte jetzt zu veröffentlichen, so lange er noch sebr jung sei, er sei dann vor ungunstiger beurteilung derselben sicherer als später oder, sollte dieselbe doch kommen, so sei sie von weniger bedeutung als später. Der titel des buichleins zeigt, dass schon damals B. glaubte, er sei 1805 geboren. B. gibt an, die gedichte seien geschrieben 'between the age of thirteen and fifteen', bemerkt aber, dass er Ismael zu Ealing (also in seinem siebzehnten jahre) geschrieben habe ${ }^{3}$. Sehr interessant ist, dass in einem gedichte Walter Scott und Campbell sehr gepriesen werden, aber Byron wegen der 'Immorality of his Muse' heftig getadelt wird. Trotzdem ist Ismael durchaus Byron nachgeahmt. Auch der weltschmerz, welcher in einigen der kleinern gedichte dieser sammlung hervortritt, ist wol mehr diesem dichter nachgeahmt als wirklich empfunden. Moore und Wordsworth werden auch gerade nicht sehr gtinstig beurteilt4. An Walter Scott ist noch ein besonderes gedicht gerichtet: Written at thirteen years old (also in wirklichkeit aus B.'s fünfzehntem jahre). Fur dieses liess Scott dem verfasser seinen dank aussprechen. Der sammlung ist ein vorwort von Wallington (unter dem namen 'Philomusos') vorausgeschickt, dann folgt ein kurzes, entschuldigendes von B. selbst. Gewidmet ist der band 'To a British Public'.

Mit dem erfolge des Ismael konnte B. sehr zufrieden sein. Diese veröffentlichung hob ihn nicht nur uber seine altersgenossen; sie verschaffte ihm auch die freundschaft von angesehenen ältern herren und damen, welche furr sein späteres

1 Vgl. s. 5. Beweise fitr die abfassung zu dieser zeit finden sich z. b. bd. 1 s. 229 anm.

2 Vgl. s. $133 \mathrm{f}$. "Then did I conceive, audax omnia perpeti, the Homeric epic of the 'Battle of Waterloo' beginning, if I remember right, with 'Awake, my Muse'! and then did I perpetrate the poem of 'Ismael: an Oriental Tale", beginning, Byron-like, with 'Tis eve', etc. and thronged with bulbuls and palm-trees. In short I was a verse-maker, and nothing more'. - S. 146: 'The verses in 'Ismael and other Poems' have no literary value'.

3 Vgl. s. 134 .

4 Vgl. s. 144 f. 
leben und seine weitere laufbahn wichtig wurden. Dass B. damals übrigens selbst schon glaubte, einmal ein berühmter mann zu werden, geht deutlich aus stellen damaliger briefe hervor ${ }^{1}$.

An das ende von Bulwer's aufenthalt in Ealing fällt die erste liebe des dichters, die für sein ganzes leben wichtig geworden ist. Durch dieselbe verstehen wir erst eine reihe seiner werke. B. lernte bei Ealing ein mädchen kennen, sie trafen sich oft zwischen Ealing und Castlebar am ufer des Brent und verlebten in ihrer unschuldigen liebe dort während eines sommers glïckliche stunden. Eines abends war das mädchen sehr traurig und obgleich sie sich wie sonst mit 'Anf widersehen morgen' trennten, kam das mädchen weder am folgenden tage noch tiberhaupt wider. Nach drei jahren erhielt $B$. einen brief, welchen seine geliebte auf dem todenbette geschrieben hatte, worin sie erzählte, wie sie zu einer ehe gezwungen immer nur $B$. geliebt habe und ihn bittet doch ihr grab zu besuchen. Sommer 1824 reiste denn auch B. an die seen, da dort das grab seiner freundin war am oder in der nähe vom Ulleswater. Den aufenthalt am grabe in einer mondnacht sowie die geschichte seiner geliebten schildert er in einem gedichte, das sicher zu dieser zeit entstand, in der Tale of a Dreamer. Dieses gedicht, welches in den 'Weeds and Wildflowers' steht, wird erst durch diese erzählung in der lebensheschreibung verständlich ${ }^{2}$. Unter der Viola wird hier das mädchen verherrlicht, dann erinnert wider Emily im Falkland an es, darauf im Student (On the Want of Sympathy) denkt er seiner und in B.'s allerletztem romane, den er nicht mehr vollenden konnte, ruft sich der greis in der gestalt der Lily seine jugendliebe wider in das gedächtniss zurlick ${ }^{3}$.

1 Man vgl. z. b. s. 150, wo B. an einen freund, Drake Garrard schreibt: '... I intend to have my letters published after my death, like every other great man. And I hope therefore you will take the hint and not destroy either by fire or sword my epistles'.

2 Vgl. Weeds and Wildflowers s. $77 \mathrm{ff}$. Es ist unterzeichnet Windermere 1825. Auch beginnt es:

'The Moon is on thy waters, Windermere'.

3 In der Biographie druckt der sohn des dichters fast das ganze: 'Tale of a Dreamer' ab. Es ist nicht gesagt, woher dieser text genommen ist. Meines wissens wurde dieses gedicht ausser in den 'Weeds and Wildflowers' nicht wider gedruckt. Und doch weicht der text ganz bedeutend von dem der W. a. W. ab. Znr vergleichung lasse ich ein stiick in beiden fassungen folgen: 
Dadurch dass nun festgestellt ist, wer die Viola in der Tale of a Dreamer sein soll, wird aber zugleich eine angabe von Bulwer selbst als falsch erwiesen. Bulwer sagt nämlich

\author{
W. a. W.
}

And thou wert beautiful, my Viola!

The hues of morning slept upon thy cheek -

The morning, ere man's step hath dash'd away

One dewdrop from the virgin flowers of earth. -

Youth - Health - and Innocence had made thee gay,

And the heart's smile, and happy laugh would break

Forth from the springtide of thy maiden mirth. -

Thine eye swam in its lustre - like the beam

Of evening's star reflected in the stream -

And the sweet gladness of thy fairy voice

Bade Pain be mute - and Sorrow's self rejoice -

We met - we saw - we lov'd - and we were blest; -

We lov'd - ye Heavens within whose glories move

The light - the soul - the element of love -

0 witness to our loves! Voluptuous hours

When Time transported, wreath'd his wings with flowers:

And Hope like Summer revell'd in the breast. -

The day break of the heart, when laughing Youth

Is still empearl'd with Childhood's freshest dew, -

When care seems made but for fresh joys to sooth,

And every charm - save Innocence - is new.

And thou sweet Love o'er youth and pleasure wreathing

The boughs all perfum'd with thine odorous sigh,

And o'er the bright Earth still more brightly breathing

The cloudless warmth of thine Italian sky; -

Beautifull (!) Spirit making all so fair -

The soul and sunlight of Life's chilling air -

Though thou art gone - and Hope hath lost its hues -

Tho' my young rapture leaves me but regret -

I will not with the vulgar herd accuse

The power which blest - betray'd - and lures me yet.

The blight may fall - the winter wing the blast -

But thy green myrtle blossoms to the last. --

\title{
Autobiography.
}

And thon wert beautiful, my Viola!

The hues of morning slept upon thy cheek:

The morning, ere man's step hath dash'd away

One dewdrop from the virgin flowers of earth.

Youth, health, and innocence had made thee gay;

And the heart's smile, and happy laugh, would break

Forth from the springtide of thy maiden mirth.

We met, we saw, we loved, and we were blest.

We loved! Ye heavens, within whose glories move

(Kindling the east and curtaining the west)

The everlasting ministers of love,

When have ye witness'd more voluptuous hours,

Diviner days more perfectly possess'd

Or bliss more innocently bold than ours?

Ah, brief, sweet, daybreak of the heart, when youth

Is fragrant still with childhood's freshest dew, 
in der 'Dedicatory Epistle' zu W. a. W.: 'One word more knowing how dangerous for our reputation is the writing of a tale, since of late years the Author has always been incorporated with the Hero, - to you and to the few who will read the slight sketch called "The Tale of a Dreamer" I most seriously disclaim all identity with the Historian and all reality in the History: It is indeed entirely fictitious, and has only been told in the first person in order to make the fen reflections it conveys the more simple, and the threadbare plot it embodies less uninteresting ....?

Es wollte also B. hier seine leser absichtlich irre fuhren. Bulwer's sohn erwähnt keines gedichtes seines vaters, das gleichzeitig mit der liebesgeschichte geschrieben wäre. Es scheint aber doch in den W. a. W. ein gedicht, welches 1820 gedichtet wurde, sich auf dieses ereigniss beziehen zu mussen. Da W. a. W. sehr selten sind, lasse ich das gedicht folgen:

1. Oh come to me mine only love, As springtide to the tree, Bring blossoms to the heart, my love, Which long has pined for thee!

2. Such gloom is on the spot, my love, Which once we thought so fair, Methinks it mourns like me, my love, Because thou art not there!

3. I want the lip from whence, my love, My latest kiss was stole, I want the voice which breathes, my love, Like west winds on my soul.

4. I want the starlight wave, my love, Which dances in thine eye, And oh! I want the step, my love, As soft as passion's sigh.

When every fair illusion is a truth, And every charm, save innocence, is new!

And thou, sweet Love, round thy discoverers wreathing

The branches perfumed by thine odorous sigh,

And o'er the bright earth still more brightly breathing

The cloudless warmth of thine Italian sky,

Tho' thou art gone, and gone with thee the hues

of life's young rapture, lost in long regret,

I will not, with the heartless herd, accuse

The power that blest, betray'd, and lures me yet.

Eine vergleichung ergibt, dass die fassung der W. a. W. jedenfalls die ïltere und breiter angelegte (33 verse gegen 26 in Autob.) ist. 
Oh come - oh come to me, my love,

As springtide to the tree,

As Morning to the night, my love,

Oh come! - oh come to me!

Wenn man ničht annehmen will, dass die angeredete geliebte nur eine erfundene gestalt des dichters sei (und dies ist unglaublich, weil das gedicht 1820 gedichtet wurde), so können wir die verse nur auf obiges ereigniss beziehen. Ausserdem scheint der dichter gerade auf dieses gedicht einen besondern wert gelegt zu haben, denn sonst findet sich ausser vielleicht dem undatirten gedichte s. $30 \mathrm{f}$. (The Spartan Mother at the Death of her Son) und dem gedichte 'Milton'1 kein gedicht, das frther als 1823 entstanden wäre. Dann ist in den W. a. W. noch ein gedicht enthalten, welches auch auf diese liebe sich bezieht, uberschrieben 'To Thee'2. Obgleich dieses aus drei zwölfzeiligen strophen bestehende gedicht erst Paris 1825 geschrieben ist, so zeigt es doch, wie sehr damals Bulwer noch unter dem eindrucke des todes seiner geliebten stand. Es schliesst:

With thee the very future fled,

I stand amid the past alone,

A tomb which still shall guard the dead

Tho' every earthlier trace be flown,

A tomb o'er which the weeds that love

Decay - their wild luxuriance wreathe! -

The cold and callous stone above -

And only thou and death beneath!

1821 bestimmte B.'s mutter, dass ihr sohn die universität Cambridge besuchen sollte, obgleich Wallington entschieden für Oxford war. B. selbst in seiner damaligen stimmung war gleichgtltig dagegen, wo er studieren solle. Da es B. zum besuche von Cambridge noch sehr an kenntnissen in der mathematik und den naturwissenschaften mangelte, erhielt er noch unterricht bei einem herren Thomson in St. Lawrence bei Ramsgate. Um weihnachten 1821 verliess er St. Lawrence

' In den W. a. W. ist das gedicht 'Milton' nicht weiter zeitlich bestimmt. Auch in der Biographie wird s. 259 das entstehungsjahr im texte nicht genau angegeben. Wir hören nur, dass zur selben zeit mit der prosafassung 'Milton' auch ein gedicht gleichen inhaltes entstanden sei. Am rande steht hier Ex. 19, dies wïrde also das jahr 1922 ergeben.

2 Vgl. Biogr. II 2i; W. a. W. s. 73 f. 
und war nun bereit die hochschule za beziehen. B. war damals an geist und körper wider etwas gekräftigter.

Sehr passend hat der herausgeber der Autobiographie an den schluss dieses abschnittes das $\mathrm{ms}$. von Lionel Hastings gestellt, eines romanes, der nie vollendet, daher auch nie veröffentlicht wurde. Wir müssen aber B.'s sohne sehr dankbar sein, dass er die vorhandnen dreizehn kapitel veröffentlichte, denn kein roman B.'s enthält soviel aus dem eignen leben des verfassers als gerade dieser. In dem verstorbnen oberst Hastings erkennt man leicht B.'s vater, in Lady Anne Hastings seine mutter, in Lionel $H$. den verfasser selbst. Dr. Hooker zu Rottendean wird als Dr. Wortham zu Puzzledean, Dr. Keate als Mr. Tuftoe, Lady Caroline Lamb als Lady Clara eingefuhrt. In den briefen, welche Dr. Wortham an Lady Hastings schreibt, sind manche gedanken, welche sich ganz ähnlich in schreiben Dr. Hooker's an B.'s mutter ausgesprochen finden. Die geschichte geht nicht tber die schulzeit des helden hinaus.

Es fragt sich, wann B. an diesem romane schrieb. B.'s sohn setzt die entstehung zwischen $1840-50$, vielleicht. vor die Caxtons, jedenfalls vor die erzählung 'What will he do with it', da in letzterem romane manches aus Hastings aufgenommen ist, wie auch schon der junge held der erzählung gleichfalls Lionel heisst.

Das dritte buch beschäftigt sich mit den studienjahren des dichters, mit·1821-1825. Diese zeit ist von B. sehr kurz dargestellt. Anfangs fuhlte sich der dichter sehr vereinsamt in Cambridge. Erst nachdem er Trinity College, wo seine zwei brtder gewesen waren, mit Trinity Hall vertauscht hatte, besonders aber nachdem er in die Union Debating Society eingetreten und dort eine stellung erlangt hatte, fuihlte er sich heimischer auf der hochschule. Er machte die bekanntschaft von Alexander Cockburn, dem er später die W. a. W. widmete, von Winthrop Mackworth Praed nnd vor allem von Macaulay. In dem gedichte 'St. Stephens', woraus ein sttick in der Biogr. gegeben ist', werden die verschiedenen grössen der Debating Society verherrlicht.

1825 wurde Bulwer graduiert und verliess Cambridge. Kurz ehe B. von der hochschule abging, bewarb cr sich noch

' Vgl. Biogr. I $234 \mathrm{f}$. 
um die goldne medaille für ein Englisches gedicht, zu dessen gegenstand 'The Sculpture' bestimmt war. Er war schon in London, als ihm mitgeteilt wurde, er habe den preis erhalten. Dass B. auf diese auszeichnung sehr stolz war, darf uns nicht wundern, war es doch der erste wirkliche erfolg. den er mit seinen dichtungen errungen hatte ${ }^{1}$.

Veröffentlicht wurde von B. während seiner Cambridger zeit ein bändchen gedichte: Delmour, or a Tale of a Sylphid, and other Poems. Es erschien 1823 bei Carpenter and Son. Ueber dieses kleine werk, das jetzt ganz aus dem buchhandel verschwunden zu sein scheint, gibt B.'s sohn leider nichts näheres an. Die widmung war an Lord Holland gerichtet und vom 19. april 1823 unterzeichnet ${ }^{2}$. Ausserdem fasste $B$. gegen ende seiner studienzeit den plan zum Falkland ('sketched the outline of the tale of (Falkland") und schrieb das erste capitel von Pelham. Ein anderer entwurf wird uns zum ersten male gedruckt vorgelegt: The Miseries of a Freshman (Leiden eines fuchses) ${ }^{\circ}$. 254-258 und ausserdem erfahren wir, dass B. in prosa schrieb, was er später im gedichte Milton in versen verherrlichte ${ }^{3}$.

1 B. gedenkt s. 237 der angriffe, welche gegen ihn in Fraser's Magazine gemacht wurden in folge des preisgedichtes und seiner spätern werke. Da er sagt: "That magazine, under the auspices of Dr. Maginn and Mr. Thackeray, long continued to assail me, not in any form that can fairly be called criticism, but with a kind of - ribald impertinence offered, so far as I can remember, to no other writer of my time'. Man kinnte denken, dass $B$. hier hauptsiichlich Thackeray im auge gehabt hätte. Für die spätere zeit ist dies sicherlich auch der fall. Allein als B. sein preisgedicht schrieb, war Th. erst vierzehn jahre alt und mit Fraser's Magazine trat or erst in verbindung, nachdem er sein vermögen verloren hatte. An einer andren stelle II $273 \mathrm{ff}$. erfahren wir näheres ther Fraser's Magazine. Hieraus ersehen wir, dass vom jahre 1838 an sich Thackeray allerdings an der verspottung B.'s in Fraser's Magazine beteiligte. Die Yellowplush-Correspondence ist zeugniss dafür, wer unter dem 'Sawedwadgeorgeearllittnbullwig' zu verstehen ist, kann keinem zweifel unterliegen. Doch hüren wir auch (s. 275 \&. a. o.), dass Thackeray später seine ausfälle gegen Bulwer sehr bereute und selbst einen entschuldigungsbrief an $\mathrm{B}$. schrieb.

2 Gerne erfuhre man, ob B. dieses werk mit seinem namen herausgab. Da er es Lord Holland widmete, ist dies wol anzuuehmen. Auch hätte man gerne etwas iiber die 'Other Poems' gehört. In den W. a W. findet sich ein kleines gedicht 'Songs of the Sylphs'. Da dieses 1823 unterzeichnet ist, so liegt die vermutung nahe, dass es in zusammenhang mit 'Delmour' stehe. Ist es vielleicht daraus entnommen?

3 Der herausgeber der Autobiographie bemerkt hierzu 8. 259 vom gedichte 'Milton': 'This poem he afterwards published in 1831, incongruously coupling it with 'The Siamese Twins'...'. Nimmt man das 
Endlich trugen B.'s studien in Englischer geschichte auch ihre fribchte. Der dichter entschloss sich zu schreiben 'History of the British Public' und davon haben wir (allerdings nur in bruchstlicken) einen ausführlichen plan des ganzen werkes. 'Der herausgeber druckt denselben ab. Er ward ansgearbeitet zu Windermere $1824^{1}$.

Das vierte buch umfasst nur 1824-25 und ist betitelt Wanderjahr'. Es behandelt B.'s aufenthalt in Windermere, von dem schon oben die rede war, und einige erzeugnisse, die in die studienzeit B.'s fallen. In spätere zeit, aber doch noch in das jahr 1825, gehören nur die erlebnisse in Frankreich, welche in cap. 13 und 14 erzählt werden.

Ausser dem schon erwähnten besuche des grabes seiner geliebten, teilt uns B. vor allem noch ein abentener bei einem ansfluge von Windermere aus mit, wo er in einem einsam gelegenen hause thbernachtet und beinahe ermordet worden wäre 2 . Weiterhin wird uns uber eine fussreise B.'s durch teile von Schottland ganz kurz berichtet, wobei B. wider durch einen jungen mann, der sich ihm als begleiter aufdrängte, in lebensgefahr geriet ${ }^{3}$. Ein aufenthalt in Scarborough, auf der rtickreise von Schottland, gibt von interessantem nur das eine, dass B. dort einen herrn kennen lernte, den er uns später im Mr. Graves im 'Money' schilderte. Ansprechend ist die schilderung, wie $B$. einige tage unter zigeunern lebte, dann aber durch ein liebesabenteuer gezwungen wurde, sie wider zu ver-

\footnotetext{
'published' ganz wurtlich, so hat der herausgeber recht. Aber zum ersten male gedruckt wurde das gedicht Milton in den W. a. W. s. 33-46. Allordings waren die W. a. W. nur für freunde gedruckt ('Not published' wie anf dem titel steht).

' Der abschnitt, worin B. seinen begriff vom 'Public' erklärte, ist leider verloren. B. versteht unter 'Public' (das er durchaus nicht mit 'People' verwechselt haben will) den teil des volkes, welcher fuir die ganze culturentwickelung desselben in einer bestimmten zeit tonangebend ist. Daher war 'the Public' in den verschiednen zeiten von verschiednen ständen vertreten.

2 Wir hören hier auch, dass ein dunkler, von finstern klippen umgebner see, an dem er vorbeiritt, als er das einsame haus erreichte, das vorbild zu dem see gab, welcher im 1. gesange des 'King Arthur' beschrieben wird (I, 51): '- a sunless pool was near, As ebon black, and yet as crystal clear'.

3 B. fuhrt nicht an, dass er das eine erlebniss, dass er iber eine tiefe schlucht sprang, in einem seiner werke verwortet habe. Es findet sich aber benutzt in 'The Caxtons' Part V Cap. 1. Auch werden manche züge des Vivian (bei seinem erstem auftreten Part IV Cap. 4) in dieser erzählung dem spitzbuben Wolffe entnommen.
} 
lassen. Bei seiner rtickkehr nach London 1824 traf der dichter seine mutter nicht dort, sie war in Broadstairs, wohin sich dann ihr: sohn begab1. Von hieraus besuchte B. Lady Caroline Lamb, zu der er sich. trotz des alterunterschiedes, sehr hingezogen fuhlte. Er hatte diese dame schon als Lady Clara in seinen romanbruchsttlcke 'Lionel Hastings' auftreten lassen. Dann findet sie sich wider als Lady Melton im Rupert de Lindsay im ersten teile, einer erzählung, welche der herausgeber der Autob. abdruckt. Bei einem besuche B.'s bei Lady Caroline endete das freundschaftliche verhältniss aber, indem die dame einen andern herrn sehr bevorzugte. B. brach daher seine beziehungen mit ihr ab. Ehe B. dann 1824 wider nach Cambridge zurtickging, besuchte er noch einen freund, Frederick Villiers, der ihm viele züge für seinen Pelham lieferte ${ }^{2}$.

Die erzählung 'Rupert de Lindsay' ist, wie Falkland und $0^{\prime}$ Niel, aus der Byronschen zeit des dichters. Sie spielt zum teil um Windermere. Manches aus dem zweiten teil (z. b. wie Rupert durch krankheit von Mary fern gehalten wird) findet sich später auch in Pelham aufgenommen. Der name Monkton wird auch im 'Falkland' verwendet, allerdings hat sonst der eine Monkton mit dem andern nichts gemeinsam. Die eigne lebensbeschreibung bricht ab mit B.'s reise nach Boulogne, dann nach Paris im herbst 1825. Er reiste dorthin mit seinem

1 B. erwähnt, dass er sich zu London (also 1824) ein schwarzmähniges Andalusisches pferd geksuft habe und fährt fort: 'I never found another horse which I had the same pleasure in riding, and, indeed, I have cared little to ride at all since its loss (nach mehr als zwanzig jahren). B.'s sohn bemerkt dazu: '. . . it is the subject of an ode in Weeds and Wildflowers'. Es kann darunter nur das gedicht gemeint sein in W. 2. W., das anfingt (s. $23 \mathrm{ff}$.): 'Come forth, my brave Steed, the sun shines on the vale - Es stimmt auch die zweite strophe:

'Let the Lover go warble his strains to the Fair, -

I regard not his rapture, and heed not his care, -

But now, as we bound o'er the mountains and lea,

I will weave, my brave Steed, a wild measure to thee.

sehr wol mit B.'s bemerkung in der Autobiographie: . . 'I have formed few friendships among my fellow-men so intimate and so enduring as I formed with this black-maned Andalusian'. Es scheint also allordings kein zweifel sein zu können, dass hier dieses Andalusische pferd gemeint ist. Aber in der Autobiographie wird 1824 angegeben, dagegen ist das gedicht 1823 nnterzeichnet. Wie stimmt dies zusammen? Da die Autob. erst in den vierziger jahren begonnen wurde, diirfen wir wol die angabe. in W. \&. W, fúr die richtigere halten.

2 Vgl. auch s. 363 . 
bekannten Frederick Villiers. In Boulogne hatte letzterer ein duell, in welchem $B$. sekundirte. Dann reisten beide bekannte zu wagen nach Brìssel und von da nach Paris.

In Paris traf B. seinen bruder Heinrich, doch kamen die bruder nur gelegentlich zusammen. Von wichtigkeit wurde für B. die bekanntschaft mit einem jesuiten, dem abte Kinsela. Dieser suchte bald eine heirat zwischen einer tochter der marquise de la Rochejacquelain und Bulwer zu stande zu bringen. B. scheint der vermählung nicht abgeneigt gewesen zu sein, doch er tuberliess die entscheidung seiner mutter. Diese erklärte sich, besonders aus religiösen gründen, dagegen: sie wollte keine katholische schwiegertochter haben. Daher brach B. den verkehr mit dieser familie ganz ab.

Wichtig ist die bemerkung, welche der dichter macht: 'Abont this time one of those visitations of great melancholy to which I was subject during all my younger life . . . came upon me, and grew strong and stronger, deep and deeper. Gradually I withdrew myself much from the gaieties natural to my youth, and lived greatly alone. I wrote some poems, which I privately printed at Paris, under the name of 'Weeds and Wildflowers'.

Erst durch dies bekenntniss verstehen wir, wie B. gedichte in den W. a. W. wie 'Knowledge' (s. 71) oder 'To my Mother' (s. 75) schreiben konnte. Bisher musste man annehmen, dass er hierin Byron's weltschmerz, weil es mode war, nachgeahmt hahe. Weiter hören wir noch aus diesem jahr: 'I also recast and nearly completed the sombre tale of 'Falkland'. B. verliess, um von seiner melancholie zu gesunden, Paris und nahm wohnung in Versailles, wo er durch körperliche ubung seine geistige frische wider zu erlangen suchte.

Hiermit bricht B.'s autobiographie ab, die in der ausgabe des sohnes den ersten band einnimmt. Gewinnen wir schon hierdurch einen viel tiefern einblick in B.'s werke als bisher, so wird diese eigene lebensbeschreibung noch ganz besonders wertvoll durch die beigaben der verschiedenen literarischen entwüre, welche der sohn' zugefügt hat und für die wir ihm zum grössten danke verpflichtet sind.

Von familienbildern sind dem reichansgestatteten werke beigegeben: ein bild B.'s als kleines kind und eines von ihm als knabe (von Lady Lamb gemalt mit der unterschrift 'Seul 
sur la Terre'), dann eines von den mtttterlichen grossältern, ein bild von B.'s vater, zwei von seiner mutter. Auch eine abbildung von Heydon Hall, von zimmern in Knebworth sowie von den ufern des Brent bei Ealing (wo die liebesgeschichte spielte) ist beigegeben, sodass wir nicht nur die handelnden personen, sondern auch die orte, wo sie lebten, näher kennen lernen. Endlich ist noch ein Facsimile von B.'s gedicht tuber Milton beigeftigt,

Den zweiten band, welcher vollständig von dem sohne des dichters geschrieben und zusammengestellt worden ist, da hier keine selbstverfasste lebensbeschreibung B.'s mehr vorliegt, werden wir im nächsten hefte besprechen. Auch er enthält des wichtigen und interessanten viel!

LEIPZIG.

R. WÜLKER. 